Vol 2 No 2 Desember 2021

Jurnal AlphaEuclidEdu

Received: 05/12/2020; Resived: 21/09/2021; Accepted: 27/12/2021

\title{
MENGATASI HAMBATAN BELAJAR DALAM MATERI PLSV MENGGUNAKAN DESAIN DIDAKTIS DENGAN SCAFFOLDING
}

\author{
${ }^{1}$ Ari Ariansyah, ${ }^{2}$ Sugiatno, ${ }^{3}$ Bistari \\ 1,2,3Pendidikan Matematika FKIP Universitas Tanjungpura Pontianak \\ Email: ariansyah06091997@gmail.com
}

\begin{abstract}
This research aimed to determine how to overcome student learning barriers in the material of onevariable linear equations using didactical design with scaffolding in class VIII of SMP Negeri 4 Sungai Raya. The form of research used in this study was didactical design research. The data source of this study were students of class VIII B of SMP Negeri 4 Sungai Raya and the data were the initial and final test answer sheets and the results of interviews. The results showed that didactic design with scaffolding can overcome student learning barriers. Before being given a didactical design with scaffolding students were not able to made mathematical models in the form of story problems, students were not able to equivalent and classify similar terms, the incompatibility of the problem solving steps ordered by the completion steps done by students, students cannot solve the problem comes to the simplest form, and students made mistakes in calculating the value of a count operation. After being given a didactical design with scaffolding students have been able to make mathematical models in the form of story questions, students have been able to equivalent and classify similar terms, the problem solving steps ordered with the completion steps done by students are appropriate, students can already solve the problem to the simplest form, and students are able to calculate the value of a calculated operation correctly even though there are a few operating errors in some problems.
\end{abstract}

Keywords: Didactical Design, Learning Obstacles, Scaffolding

\section{Pendahuluan}

Permasalahan dalam belajar matematika sering kali terjadi pada setiap siswa, bukan hanya siswa yang lambat saja, tetapi juga terjadi pada siswa yang cerdas. Permasalahan belajar tersebut terjadi cenderung berulang. Menurut pandangan beberapa ahli, permasalahan belajar itu dinamakan mereka hambatan, kesulitan, dan kesalahan belajar (Brousseo, 2002; Suryadi, 2010; Moru, 2006).

Hambatan mengandung banyak arti dalam setiap melaksanakan suatu tugas atau dalam suatu masalah tertentu. Moru (2006) menyatakan bahwa hambatan adalah sesuatu yang menghalangi pembelajaran siswa. Hambatan yang sering dihadapi oleh siswa pada umumnya dikenal dengan hambatan belajar. terjadinya hambatan belajar sesuai dengan pendapat yang telah disampaikan oleh Brousseo (2002: 86) disebabkan oleh beberapa faktor diantaranya: (1) hambatan ontogeni adalah hambatan yang berkaitan dengan kesiapan mental siswa dalam pembelajaran; (2) hambatan didaktis adalah hambatan yang berkaitan dengan bahan ajar atau cara guru mengajar yang diterapkan di dalam kelas pada saat proses pembelajaran berlangsung; dan (3) hambatan epistemologi adalah hambatan yang berkaitan dengan keterbatasan pengetahuan yang dimiliki siswa sehingga pengetahuan yang dimiliki sebelumnya tidak dapat digunakan secara utuh. Brousseau (1997: 86) mengemukakan bahwa hambatan epistemologis adalah hambatan yang terjadi akibat keterbatasan siswa pada konteks tertentu, ketika siswa dihadapkan 
dengan konteks baru siswa tampak kebingungan. Secara hirarkis hambatan belajar dapat menyebabkan siswa mengalami kesulitan belajar (Saputro et al., 2015); (Ernawati et al., 2017).

Menurut Irham (2017: 254) sebuah permasalahan yang mengakibatkan siswa belum mampu mengikuti proses pembelajaran secara baik seperti siswa lain pada umumnya yang disebabkan oleh faktor-faktor tertentu sehingga siswa tersebut terlambat atau bahkan tidak dapat mengikuti pembelajaran dengan baik sesuai dengan yang diharapkan dinamakan sebagai kesulitan belajar. Dengan demikian, adanya kesulitan serta hambatan dalam pembelajaran yang dialami siswa akan berdampak pada menurunnya prestasi belajar. Satu diantara materi yang menyebabkan siswa terhambat dan dianggap sulit bagi siswa adalah materi persamaan linear satu variabel (PLSV) (Rasmania et al., 2018).

Berdasarkan kurikulum 2013, PLSV merupakan satu diantara materi yang diajarkan di SMP. PLSV penting dipelajari siswa karena materi ini banyak kaitannya dengan materi selanjutnya, diantaranya pertidaksamaan linear satu variabel, Sistem persamaan linear dua varibel, dll . Materi PLSV banyak penerapannya dalam kehidupan sehari-hari misalnya untuk membagi waktu dalam menyelesaikan suatu pekerjaan, menentukan banyaknya uang untuk membeli sejumlah barang, dan dapat memnentukan umur seseorang. Mengingat pentingnya materi PLSV tersebut, diharapkan siswa mampu menguasai materi dengan benar. Namun kenyataan di lapangan masih banyak siswa kebingungan dalam menyelesaikan soal terkait PLSV yang disebabkan karena siswa masih merasa kesulitan dalam menyelesaikan soal tersebut. Kesulitan belajar mengakibatkan siswa sering kali melakukan kesalahan. Sejalan dengan itu Febrianti (2014: 25 ); (Saputro et al., 2015), melakukan penelitian dengan judul Identifikasi Kesalahan Siswa Kelas VII SMP Muhammadiyah Terpadu Kota Bengkulu Dalam Menyelesaikan Soal-Soal Persamaan Dan Pertidaksamaan Linier Satu Variabel yang menyatakan bahwa kesalahan-kesalahan yang dilakukan siswa pada saat mengerjakan soal terkait PLSV meliputi: kesalahan konsep, kesalahan prosedur, kesalahan operasi hitung dan tidak memberikan jawaban. Adapun faktor penyebabnya antara lain: (1) ketidaktelitian siswa dalam membaca soal; (2) siswa masih kebingungan dalam membedakan antara koefesien, variabel, dan konstanta; (3) siswa masih belum mampu memahami maksud dari soal yang diberikan sehingga belum mengerti cara mengekuivalenkan kedua ruas; (4) siswa kurang paham cara mengubah soal bentuk cerita menjadi model matematika.

Hasil penelitian tersebut sejalan berdasarkan pengalaman peneliti pada saat praktek pengalaman lapangan (PPL) di SMPN 4 Sungai Raya tahun pelajaran 2018/2019 yang mana fakta lapangan membuktikan bahwa faktor penyebab siswa mengalami kesulitan diantaranya (1) siswa kebingungan dalam memahami soal yang diberikan; (2) kesulitan dalam membuat model matematika pada soal cerita; (3) siswa kebingungan membedakan anatara koefesien, variabel, dan konstanta (4) siswa kesulitan ketika mengekuivalenkan kedua ruas dan kesulitan mengoperasikan. Berdasarkan kesalahan yang dilakukan siswa dan ketiga faktor dalam hambatan belajar terlihat bahwa 
hambatan yang dialami siswa di SMPN 4 Sungai Raya adalah hambatan yang berkaitan dengan aspek hambatan epistemologis. Berdasarkan riset terdahulu tentang permasalahan hambatan belajar yang dihadapi siswa dan sampai saat ini belum ditemukan bagaimana cara mengatasinya terkhusus pada materi PLSV, oleh sebab itu pada penelitian ini akan dibahas cara mengatasi hambatan belajar siswa.

Dari hambatan belajar yang dipaparkan sebelumnya, perlu suatu cara yang diberikan untuk mengatasi hambatan tersebut . Satu diantaranya menggunakan desain didaktis dengan scaffolding. Nur'aeni,Dkk (2016) menyatakan bahwa Desain didaktis adalah bentuk rencana pembelajaran dari bahan ajar yang berfungsi untuk mengurangi atau menghilangkan hambatan dalam belajar. Penelitian mengenai desain didaktis untuk mengatasi hambatan epistemologis telah banyak dilakukan peneliti sebelumnya, diantaranya: Hanafi (2015) yang melakukan penelitian tentang desain didaktis pembelajaran matematika untuk mengatasi hambatan epistimologis pada konsep limit fungsi aljabar. Hasil penelitian tersebut menunjukan perubahan, artinya setelah dilakukan perlakuan desain didaktis terlihat bahwa hambatan epistemologis yang teridentifikasi sebelumnya tidak muncul lagi. Madona (2013) juga melakukan penelitian mengenai desain didaktis konsep limit fungsi aljabar pada pembelajaran matematika SMA. Hasil penelitian juga menunjukan bahwa desain didaktis yang disusun cukup efektif dan berhasil dalam mengatasi kesulitan siswa saat memahami konsep tersebut.

Berdasarkan paparan tersebut, peneliti tertarik untuk mengatasi hambatan belajar yang terjadi pada siswa terkhusus dalam materi PLSV . Oleh karena itu peneliti ingin mengangkat judul untuk dijadikan penelitian yaitu "Mengatasi Hambatan Belajar Siswa Dalam Materi Persamaan Linear Satu Variabel Menggunakan Desain Didaktis dengan Scaffolding di Sekolah Menengah Pertama (SMP)”

Tujuan umum penelitian ini adalah untuk mengetahui Bagaimana Mengatasi/ Meminimalisir Hambatan Belajar Siswa Dalam Materi PLSV Menggunakan Desain Didaktis dengan Scaffolding Di Kelas VIII SMPN 4 Sungai Raya . Adapun secara khusus tujuan dalam penelitian ini adalah sebagai berikut: (1) Mengungkap hambatan epistemologis siswa sebelum diberikan pendekatan desain didaktis dengan scaffolding dalam materi persamaan linear satu variabel; (2) Mendeskripsikan rancangan pendekatan desain didaktis dengan scaffolding dalam materi persamaan linear satu variabel; (3) Mengeksplanasi perubahan hambatan epistemologis siswa setelah diberikan pendekatan desain didaktis dengan scaffolding dalam materi persamaan linear satu variabel; (4) Memperjelas eksplanasi pendekatan desain didaktis dengan scaffolding untuk mengatasi hambatan epistemologis siswa dalam materi PLSV.

\section{Metode Penelitian}

Bentuk penelitian yang digunakan dalam penelitian ini adalah menggunakan Didactical Design Research. Menurut Suryadi (2010) Didactical Design Research adalah penelitian yang terdiri dari tiga tahapan diantaranya: (a) Analisis situasi didaktis sebelum pembelajaran dimulai yang berupa dugaan kemungkinan kesulitan belajar siswa/ respon yang diberikan siswa, (b) Analisis Metapedadidaktik, serta (c) Analisis 
Retrosfektif yaitu analisis yang mengaitkan hasil analisis situasi didaktis hipotesis dengan hasil analisis metapedadidaktik.

Teknik purposive sampling digunakan untuk pemilihan siswa yang dijadikam sebagai subjek penelitian. Menurut American Journal of Theoretical and Applied Statistics (2016) purposive sampling juga disebut judgment sampling yaitu salah satu teknik non random yang melakukannya tidak perlu teori khusus yang mendasarinya tetapi pemilihan subjek yang dilakukan secara sengaja karena kebutuhan dalam penelitian. Subjek dalam penelitian ini adalah 6 siswa kelas VIIIB SMPN 4 Sungai Raya.

Objek dalam penelitian adalah suatu yang akan diselidiki selama kegiatan penelitian (Fitrah dan Luthfiansyah, 2017: 156). Berdasarkan tujuan yang sudah dikemukakan, maka objek dalam penelitian ini adalah learning obstacle (hambatan epistemologi) dalam materi persamaan linear satu variabel.

Alat pengumpulan data yang digunakan dalam penelitian ini adalah berupa tes dan wawancara. Tes adalah serangkaian pertanyaan atau sejenisnya yang digunakan peneliti untuk mengukur keterampilan, pengetahuan, intelegensi, kemampuan, atau bakat yang dimiliki oleh individu atau kelompok. Tes dalam penelitian ini terdiri dari tes awal dan tes akhir (Mahmud, 2011: 185). Pada tes awal, tes tersebut digunakan untuk mengungkap hambatan belajar khususnya hambatan epistemologis terkait dengan materi PLSV. Sedangkan tes akhir digunakan untuk mengetahui apakah hambatan belajar terkhusus hambatan epistemologis dalam materi PLSV masih muncul kembali atau tidak setelah dilakukan implementasi desain didaktis dengan scaffolding.

Wawancara adalah interaksi berupa tanya jawab yang dilakukan oleh dua pihak, yaitu si pewawancara yang memberikan pertanyaan untuk menggali informasi yang dibutuhkan dan yang diwawancarai untuk memberikan jawaban atas pertanyaan yang telah diberikan (Moleong, 2016: 186). Dalam penelitian kualitatif wawancara terdiri dari wawancara terstruktur dan wawancara tidak terstruktur. Adapun wawancara yang digunakan dalam penelitian ini adalah wawancara tidak terstruktur.

Dalam penelitian ini, wawancara dilakukan kepada 6 siswa yang dianggap paling banyak mengalami learning obstacle berdasarkan hasil tes awal. Adapun tujuan dari wawancara dalam penelitian ini adalah untuk mengetahui hambatan belajar yang dialami oleh siswa dalam mengerjakan soal yang diberikan terkait persamaan linear satu variabel. Sehingga akan memungkinkan peneliti mengetahui gambaran mengenai learning obstacle yang dihadapi serta mempermudah peneliti pada saat membuat desain didaktis.

Menurut Barbara (2014) analisis data adalah proses mengurangi sejumlah besar data yang telah dikumpulkan agar masuk akal. Teknik analisis data adalah suatu teknik analisis yang digunakan untuk menjawab rumusan masalah atau menguji hipotesis yang telah dirumuskan dalam proposal (Sugiyono, 2016: 333). Teknik analisis data yang dilakukan pada penelitian ini terfokus pada jawaban tes awal dan tes akhir siswa dan respon atau jawaban siswa ketika di wawancarai. 


\section{Hasil Penelitian dan Pembahasan}

\subsection{Hasil Penelitian}

Hasil Tabel 1. Hasil Penelitian Hambatan pada Tes Awal dan Tes Akhir

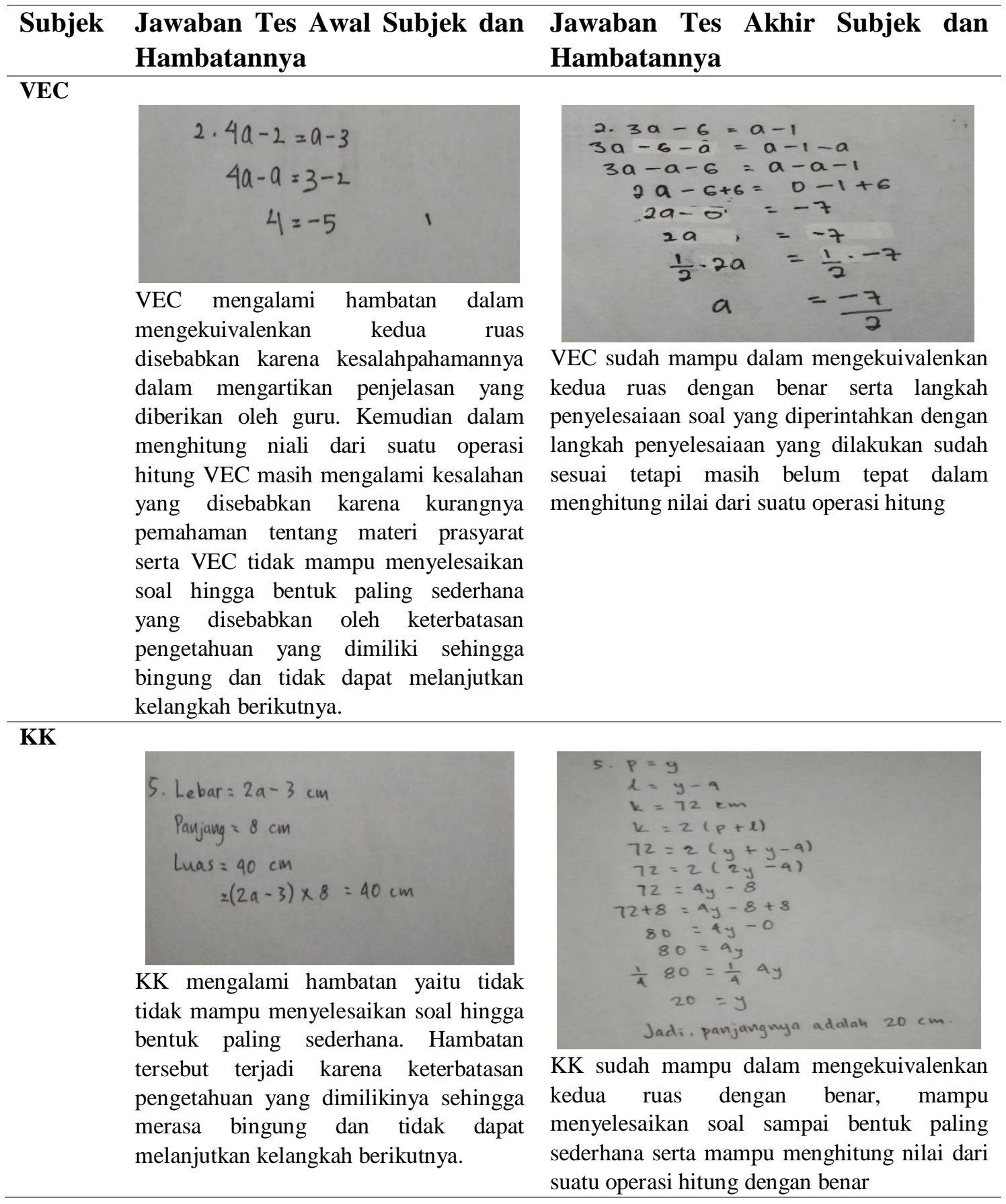


M mengalami hambatan dalammembuat model matematika, mengekuivalenkan kedua ruas, langkah penyelesaiaan soal yang diperintahkan dengan langkah penyelesaiaan yang dilakukannya tidak sesuai serta mengalami hambatan dalam mengoperasikan. Hambatan tersebut terjadi karena keterbatasan pengetahuan yang dimiliki subjek yang disebabkan karean ketidakmampuannya mengingat materi sebelumnya (lupa).

JA

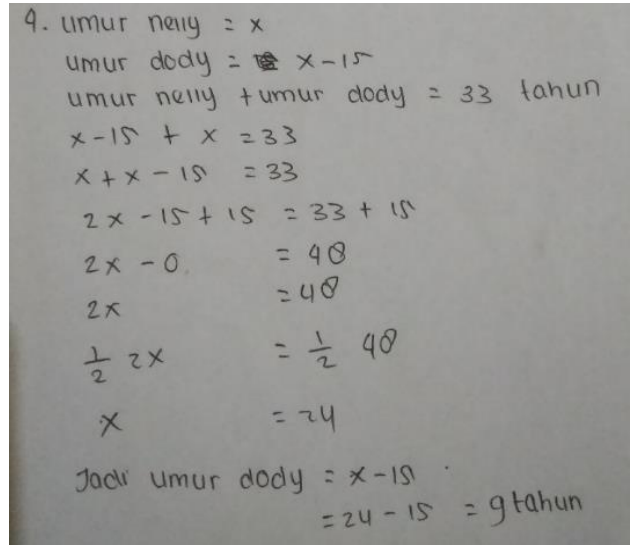

M sudah mampu dalam mengekuivalenkan kedua ruas dengan benar, langkah penyelesaiaan soal yang diperintahkan dengan langkah penyelesaiaan yang dilakukan sudah sesuai serta mampu menghitung nilai dari suatu operasi hitung dengan benar

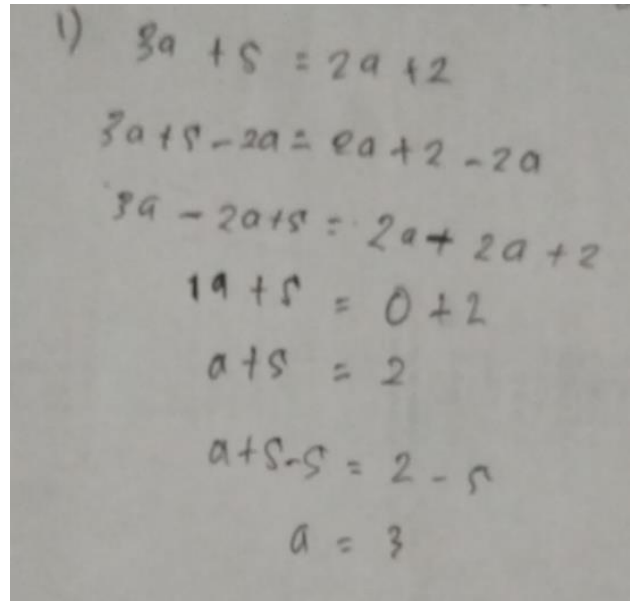

JA sudah mampu dalam mengekuivalenkan kedua ruas dan dapat menyelesaikan soal sampai bentuk paling sederhana tetapi masih melakukan kesalahan menghitung nilai dari suatu operasi hitung. 


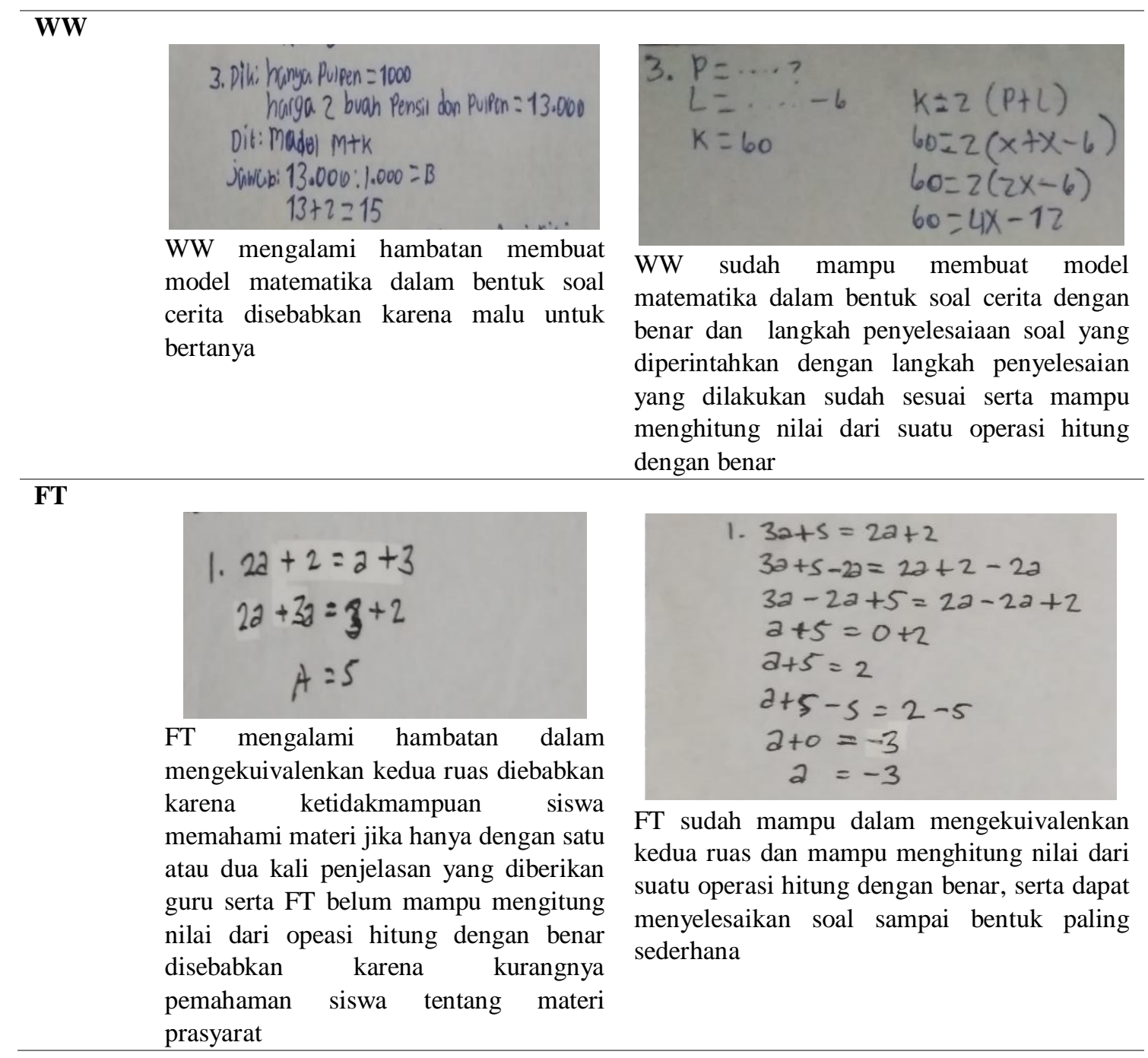

Berdasarkan tes awal, keenam subjek dalam materi PLSV masih mengalami hambatan, baik itu terkait konseptual, prosedural, maupun teknik operasional. Hambatan konseptual yang dialami subjek yaitu: (1) Subjek tidak mampu membuat model matematika dalam bentuk soal cerita; (2) Subjek tidak mampu dalam mengekuivalenkan dan mengelompokkan suku-suku yang sejenis (sama). Hambatan prosedural yang dialami subjek yaitu: (1) Ketidaksesuaian langkah penyelesaiaan soal yang diperintahkan dengan langkah penyelesaiaan yang dilakukan siswa; (2) Subjek tidak dapat menyelesaikan soal sampai pada bentuk paling sederhana. Hambatan teknik operasional yang dialami subjek yaitu: (1) Subjek melakukan kesalahan dalam menghitung niali dari suatu operasi hitung.

\subsection{Pembahasan}

Pada tahap pertama peneliti memberikan tes awal bertujuan untuk mengungkap hambatan yang terjadi pada siswa. Setelah ditemukannya hambatan tersebut selanjutnya peneliti merancang desain didaktis dengan scaffolding sesuai dengan hambatan yang diialami siswa bertujuan agar hambatan tersebut tidak terjadi lagi atau 
terminimalisir. Tahap kedua, peneliti memberikan implementasi desain didaktis dengan scaffolding yang sudah dibuat kepada 6 orang subjek yang bertujuan untuk mengatasi learning obstacle (hambatan epistemologi) dalam materi persamaan linear satu variabel.

Pada saat implementasi desain didaktis dengan scaffolding diberikan kepada 6 subjek secara bersamaan, scaffolding yang diberikan pada saat pembelajaran yaitu: (1) Mengingatkan subjek mengenai koefesien, variabel dan konstanta; (2) Mengingatkan subjek mengenai suku-suku yang sejenis; (3) Menjelaskan cara mengekuivalenkan kedua ruas dan mengelompokkan suku yang sejenis dengan benar; (4) Mengingatkan kembali tentang materi opersai bilangan bulat dan operasi bentuk aljabar; (5) Menjelaskan cara mengoperasikan dengan benar; (6) Membimbing siswa membuat model matematika dalm bentuk soal cerita; (7) Membimbing siswa langkah demi langkah hingga pada langkah terakhir. Selain itu juga peneliti memberikan scaffolding secara individu kepada subjek yang masih mengalami hambatan dengan cara menanyakan kembali bagian yang belum mereka pahami dan mejelaskan secara runtut.

Hambatan konseptual yang dialami VEC yaitu tidak mampu dalam mengekuivalenkan kedua ruas, tidak mampu dalam mengelompokkan suku-suku yang sejenis (sama), tidak mampu membuat model matematika dalam bentuk soal cerita. Hambatan konseptual tersebut terjadi karena disebabkan oleh beberapa faktor. Berdasarkan hasil wawancara peneliti dengan subjek VEC faktor penyebeb VEC salah dalam mengekuivalenkan kedua ruas dan salah dalam mengelompokkan suku sejenis, peneliti menyimpulkan bahwa terjadi kesalahpahaman subjek dalam mengartikan penjelasan yang diberikan oleh guru. kemudian berdasarkan hasil wawancara juga penyebab subjek VEC salah dalam membuat model matematika adalah ketidakmampuannya mengingat materi sebelumnya (lupa). Dengan scaffolding peneliti meluruskan kesalahpahaman tersebut dengan cara membimbing dan menjelaskan cara mengekuivalenkan dan mengelompokkan suku sejenis serta mengingatkan dan membimbing subjek membuat model matematika dengan benar. Ternyata setelah implementasi kesalahpahaman subjek VEC sudah dapat teratasi dan sudah dapat mengingat materi sebelumnya sehingga subjek sudah mampu dalam menekuivalenkaan kedua ruas, mengelompokkan suku sejens serta membuat model matematika.

Hambatan prosedural yang dialami VEC adalah ketidakmampuanya dalam menyelesaikan soal sampai bentuk paling sederhana. Berdasarkan hasil wawancara peneliti dengan subjek hambatan tersebut disebabkan oleh keterbatasan pengetahuan yang dimiliki sehingga merasa bingung dan tidak dapat melanjutkan kelangkah berikutnya. Dengan scaffolding peneliti menjelaskan cara menyelesaikan soal secara sistematis hingga bentuk paling sederhana. Ternyata setelah implementasi subjek tidak merasa bingung lagi dan sudah dapat menyelesaikan soal sampai bentuk paling sederhana.

Hambatan teknik operasional yang dialami VEC adalah melakukan kesalahan dalam menghitung niali dari suatu operasi hitung. Berdasarkan hasil wawancara peneliti dengan subjek hambatan tersebut disebabkan karena kurangnya pemahaman tentang materi prasyarat. Dengan scaffolding peneliti mengingatkan kembali operasi 
bentuk aljabar dan menjelaskan cara menghitung nilai dari suatu operasi hitung dengan benar. Ternyata setelah implementasi subjek VEC sudah mampu menghitung dengan benar pada soal no 2, 3, 4, dan 5. Namun masih mengalami sedikit kesalahan mengoperasikan pada soal no 1 disebabkan karena keterbatasan pengetahuan subjek terkait materi prasyarat.

Hambatan konseptual yang dialami KK yaitu tidak mampu dalam mengekuivalenkan kedua ruas, tidak mampu dalam mengelompokkan suku-suku yang sejenis (sama), tidak mampu membuat model matematika dalam bentuk soal cerita. Hambatan konseptual tersebut terjadi karena disebabkan oleh beberapa faktor. Berdasarkan hasil wawancara peneliti dengan subjek KK faktor penyebeb KK salah dalam mengekuivalenkan kedua ruas dan salah dalam mengelompokkan suku sejenis, peneliti menyimpulkan bahwa terjadi kesalahpahaman subjek dalam mengartikan penjelasan yang diberikan oleh guru. kemudian berdasarkan hasil wawancara juga penyebab subjek KK salah dalam membuat model matematika adalah subjek kurang mendengarkan penjelasan guru karena suasana kelas yang tidak kondusif. Dengan scaffolding peneliti meluruskan kesalahpahaman tersebut dengan cara membimbing dan menjelaskan cara mengekuivalenkan dan mengelompokkan suku sejenis serta membimbing subjek membuat model matematika dengan benar. Ternyata setelah implementasi kesalahpahaman subjek KK sudah dapat teratasi dan subjek sudah mampu dalam menekuivalenkaan kedua ruas, mengelompokkan suku sejens serta membuat model matematika dengan benar.

Hambatan prosedural yang dialami KK adalah ketidakmampuanya dalam menyelesaikan soal sampai bentuk paling sederhana. Berdasarkan hasil wawancara peneliti dengan subjek hambatan tersebut disebabkan oleh keterbatasan pengetahuan yang dimiliki sehingga merasa bingung dan tidak dapat melanjutkan kelangkah berikutnya. Dengan scaffolding peneliti menjelaskan cara menyelesaikan soal secara sistematis hingga bentuk paling sderhana. Ternyata setelah implementasi subjek tidak merasa bingung lagi dan sudah dapat menyelesaikan soal sampai bentuk paling sederhana.

Hambatan konseptual yang dialami $\mathrm{M}$ yaitu tidak mampu dalam mengekuivalenkan kedua ruas, tidak mampu dalam mengelompokkan suku-suku yang sejenis (sama), tidak mampu membuat model matematika dalam bentuk soal cerita. Hambatan konseptual tersebut terjadi karena disebabkan oleh beberapa faktor. Berdasarkan hasil wawancara peneliti dengan subjek $\mathrm{M}$ faktor penyebeb $\mathrm{M}$ salah dalam mengekuivalenkan kedua ruas dan salah dalam mengelompokkan suku sejenis, peneliti menyimpulkan bahwa terjadi kesalahpahaman subjek dalam mengartikan penjelasan yang diberikan oleh guru. kemudian berdasarkan hasil wawancara juga penyebab subjek $\mathrm{M}$ salah dalam membuat model matematika adalah ketidakmampuannya mengingat materi sebelumnya (lupa). Dengan scaffolding peneliti meluruskan kesalahpahaman tersebut dengan cara membimbing dan menjelaskan cara mengekuivalenkan dan mengelompokkan suku sejenis serta mengingatkan dan membimbing subjek membuat model matematika dengan benar. Ternyata setelah implementasi kesalahpahaman subjek M sudah dapat 
teratasi dan sudah dapat mengingat materi sebelumnya sehingga subjek sudah mampu dalam mengekuivalenkaan kedua ruas, mengelompokkan suku sejens serta membuat model matematika dengan benar.

Hambatan prosedural yang dialami $M$ adalah ketidakmampuanya dalam menyelesaikan soal sampai bentuk paling sederhana, langkah penyelesaiaan soal yang diperintahkan dengan langkah penyelesaiaan yang dilakukan siswa tidak sesuai. Berdasarkan hasil wawancara peneliti dengan subjek hambatan tersebut disebabkan oleh keterbatasan pengetahuan yang dimiliki sehingga merasa bingung dan tidak dapat melanjutkan kelangkah berikutnya. Dengan scaffolding peneliti menjelaskan cara menyelesaikan soal secara sistematis hingga bentuk paling sderhana. Ternyata setelah implementasi subjek tidak merasa bingung lagi dan sudah dapat menyelesaikan soal sampai bentuk paling sederhana.

Hambatan teknik operasional yang dialami $\mathrm{M}$ adalah dalam menghitung niali dari suatu operasi hitung $\mathrm{M}$ masih mengalami kesalahan. Berdasarkan hasil wawancara peneliti dengan subjek hambatan tersebut disebabkan karena kurangnya pemahaman tentang materi prasyarat. Dengan scaffolding peneliti mengingatkan kembali operasi bilangan bulat dan menjelaskan cara menghitung nilai dari suatu operasi hitung dengan benar. Ternyata setelah implementasi subjek $M$ sudah mampu menghitung nilai dari suatu operasi hitung dengan benar.

Hambatan konseptual tersebut terjadi karena disebabkan oleh beberapa faktor. Berdasarkan hasil wawancara peneliti dengan subjek JA faktor penyebeb JA salah dalam mengekuivalenkan kedua ruas dan salah dalam mengelompokkan suku sejenis karena guru yang bersangkutan terlalu cepat dalam menjelaskan materi yang berkaitan dengan PLSV. kemudian berdasarkan hasil wawancara juga penyebab subjek JA salah dalam membuat model matematika adalah ketidakmampuannya mengingat materi sebelumnya (lupa). Dengan scaffolding secara perlahan dan tidak terburu-terburu peneliti menjelaskan cara mengekuivalenkan dan mengelompokkan suku sejenis serta mengingatkan dan membimbing subjek membuat model matematika dengan benar. Ternyata setelah implementasi subjek JA sudah mampu dalam mengekuivalenkaan kedua ruas, mengelompokkan suku sejens serta membuat model matematika dengan benar.

Hambatan prosedural yang dialami JA adalah ketidakmampuanya dalam menyelesaikan soal sampai bentuk paling sederhana. Berdasarkan hasil wawancara peneliti dengan subjek hambatan tersebut disebabkan oleh keterbatasan pengetahuan yang dimiliki sehingga merasa bingung dan tidak dapat melanjutkan kelangkah berikutnya. Dengan scaffolding peneliti menjelaskan cara menyelesaikan soal secara sistematis hingga bentuk paling sderhana. Ternyata setelah implementasi subjek tidak merasa bingung lagi dan sudah dapat menyelesaikan soal sampai bentuk paling sederhana.

Hambatan teknik operasional yang dialami JA adalah dalam menghitung niali dari suatu operasi hitung JA masih mengalami kesalahan. Berdasarkan hasil wawancara peneliti dengan subjek hambatan tersebut disebabkan karena kurangnya pemahaman 
tentang materi prasyarat. Dengan scaffolding peneliti mengingatkan kembali operasi bentuk aljabar dan menjelaskan cara menghitung nilai dari suatu operasi hitung dengan benar. Ternyata setelah implementasi subjek JA sudah mampu menghitung nilai dari suatu operasi hitung dengan benar pada soal no 2,3,4. Namun masih mengalami sedikit kesalahan mengoperasikan pada soal no 1 dan no 5 disebabkan karena kekeliruan atau ketidaktelitian karena tidak mngecek ulang jawaban yang telah dituliskan

Subjek WW dalam materi persamaan linear satu variabel sebelum diberikan desain didaktis dengan scaffolding masih mengalami hambatan, baik itu hambatan konseptual, hambatn prosedural, maupun hambatan teknik operasional.

Hambatan konseptual yang dialami WW yaitu tidak mampu dalam mengekuivalenkan kedua ruas, tidak mampu dalam mengelompokkan suku-suku yang sejenis (sama), tidak mampu membuat model matematika dalam bentuk soal cerita. Hambatan konseptual tersebut terjadi karena disebabkan oleh beberapa faktor. Berdasarkan hasil wawancara peneliti dengan subjek WW faktor penyebeb WW salah dalam mengekuivalenkan kedua ruas, salah dalam mengelompokkan suku sejenis, dan salah dalam membuat model matematika dikarenakan subjek malu untuk bertanya. Dengan scaffolding peneliti membimbing dan menjelaskan cara mengekuivalenkan dan mengelompokkan suku sejenis serta membimbing subjek membuat model matematika dengan benar. Setelah itu, peneliti memberikan scaffolding secara individu kepada subjek dengan cara menghampiri dan menanyakan kepada subjek terkait yang belum ia pahami serta menjelaskannya. Selain itu juga peneliti memberikan motivasi agar subjek berani untuk bertanya jika belum memahami materi yang dijelaskan oleh guru. Ternyata setelah implementasi subjek WW sudah dapat teratasi, dan subjek sudah mampu dalam mengekuivalenkaan kedua ruas, mengelompokkan suku sejens serta membuat model matematika dengan benar.

Hambatan prosedural yang dialami WW adalah ketidakmampuanya dalam menyelesaikan soal sampai bentuk paling sederhana, ketidaksesuaiaan langkah penyelesaiaan soal yang diperintahkan dengan langkah penyelesaiaan yang dilakukan. Berdasarkan hasil wawancara peneliti dengan subjek hambatan tersebut disebabkan karena subjek tidak terbiasa membuat langkah penyelesaian secara sistematis. Dengan scaffolding peneliti menjelaskan cara menyelesaikan soal secara sistematis hingga bentuk paling sderhana. Ternyata setelah implementasi subjek dapat menyelesaikan soal sampai bentuk paling sederhana.

Hambatan teknik operasional yang dialami WW adalah dalam menghitung niali dari suatu operasi hitung WW masih mengalami kesalahan. Berdasarkan hasil wawancara peneliti dengan subjek hambatan tersebut disebabkan karena kurangnya pemahaman tentang materi prasyarat. Dengan scaffolding peneliti mengingatkan kembali operasi bentuk aljabar dan menjelaskan cara menghitung nilai dari suatu operasi hitung dengan benar. Ternyata setelah implementasi subjek WW sudah mampu menghitung nilai dari suatu operasi hitung dengan benar.

Hambatan konseptual yang dialami FT yaitu tidak mampu dalam mengekuivalenkan kedua ruas, tidak mampu dalam mengelompokkan suku-suku yang 
sejenis (sama), tidak mampu membuat model matematika dalam bentuk soal cerita. Hambatan konseptual tersebut karena disebabkan oleh beberapa faktor. Berdasarkan hasil wawancara peneliti dengan subjek FT faktor penyebeb FT salah dalam mengekuivalenkan kedua ruas, salah dalam mengelompokkan suku sejenis, dan salah dalam membuat model matematika dikarenakan ketidakmampuan FT memahami materi jika hanya dengan satu atau dua kali penjelasan yang diberikan guru. Dengan scaffolding peneliti membimbing dan menjelaskan cara mengekuivalenkan dan mengelompokkan suku sejenis serta membimbing subjek membuat model matematika dengan benar. Setelah itu, peneliti memberikan scaffolding secara individu kepada subjek dengan cara menghampiri dan menanyakan kepada subjek terkait yang belum ia pahami serta menjelaskannya. Ternyata setelah implementasi subjek FT sudah dapat teratasi, dan subjek sudah mampu dalam mengekuivalenkaan kedua ruas, mengelompokkan suku sejens serta membuat model matematika dengan benar.

Hambatan prosedural yang dialami FT adalah ketidakmampuanya dalam menyelesaikan soal sampai bentuk paling sederhana, ketidaksesuaiaan langkah penyelesaiaan soal yang diperintahkan dengan langkah penyelesaiaan yang dilakukan. Berdasarkan hasil wawancara peneliti dengan subjek hambatan tersebut disebabkan karena subjek tidak terbiasa membuat langkah penyelesaian secara sistematis. Dengan scaffolding peneliti menjelaskan cara menyelesaikan soal secara sistematis hingga bentuk paling sderhana. Ternyata setelah implementasi subjek dapat menyelesaikan soal sampai bentuk paling sederhana.

Hambatan teknik operasional yang dialami FT adalah dalam menghitung niali dari suatu operasi hitung FT masih mengalami kesalahan. Berdasarkan hasil wawancara peneliti dengan subjek hambatan tersebut disebabkan karena kurangnya pemahaman tentang materi prasyarat. Dengan scaffolding peneliti mengingatkan kembali operasi bentuk aljabar dan menjelaskan cara menghitung nilai dari suatu operasi hitung dengan benar. Ternyata setelah implementasi subjek FT sudah mampu menghitung nilai dari suatu operasi hitung dengan benar.

Dari hasil analisis 6 subjek terlihat bahwa hambatan yang dialami subjek pada tes awal berkurang bahkan tidak muncul kembali pada saat diberikan desain didaktis dengan scaffolding. Artinya, desain didaktis dengan scaffolding cukup berhasil dalam mengatasi/meminimalisir hambatan epistemologi khusunya pada materi persamaan linear satu variabel. Serta respon dari subjek juga terbilang cukup baik ketika peneliti menanyakan perlakuan yang diberikan pada saat penelitian berlangsung.

\section{Kesimpulan}

Berdasarkan hasil jawaban tes awal sebelum diberikan perlakuan menggunakan desain didaktis dengan scaffolding terlihat bahwa subjek mengalami hambatan baik itu konseptual, prosedural, maupun teknik operasional. Adapun desain didaktis dengan scaffolding yang diberikan untuk mengatasi hambatan tersebut berupa: Mengingatkan subjek mengenai koefesien, variabel dan konstanta, mengingatkan subjek mengenai suku-suku yang sejenis, menjelaskan cara mengekuivalenkan kedua ruas dan 
mengelompokkan suku yang sejenis dengan benar, mengingatkan kembali tentang materi opersai bilangan bulat dan operasi bentuk aljabar, menjelaskan cara mengoperasikan dengan benar, membimbing siswa membuat model matematika dalm bentuk soal cerita, embimbing siswa langkah demi langkah hingga pada langkah terakhir. Selain itu juga peneliti memberikan scaffolding secara individu kepada subjek yang masih mengalami hambatan dengan cara menanyakan kembali bagian yang belum mereka pahami dan mejelaskan secara runtut. Berdasarkan hasil jawaban tes akhir yang diberikan setelah implementasi desain didaktis dengan scaffolding terlihat bahwa hambatan yang muncul pada saat tes awal menjadi berkurang atau bahkan tidak muncul lagi pada saat diberikan tes akhir. Dengan demikian Desain didaktis dengan scaffolding dapat mengatasi/ meminimalisir sebagian besar hambatan yang dialami subjek

\section{Referensi}

Barbara, kawulich. (2014). Data Analysis Techniques in Qualitative Research. In Darla Twale (Ed) Jornal of Research in Education.14(1)p. 96 - 113.

Brousseau, G. (1997). Theory Of Didactical Situations In Mathematics. Dordrecht: Kluwer Academic Publishers.

Anonim. (2002). Theory Of Didactical Situations In Mathematics. Vol 19. America: Kluwer Academic Publishers.

Ernawati, Suratman, D., \& Bistari. (2017). Pengembangan desain didaktis penalaran spasial dan penalaran kuantitif dalam materi teorema pythagoras di smp. Jurnal Penelitian, $1-10$. http://jurnal.untan.ac.id/index.php/jpdpb/article/view/22867/18131

Rasmania, Sugiatno, S., \& Suratman, D. (2018). Hambatan Epistimologis Siswa Dalam Menentukan Domain Dan Range Fungsi Kuadrat Di Sekolah Menengah Atas. Jurnal Pendidikan Dan Pembelajaran Khatulistiwa, 7(7), 1-9.

Saputro, M., Yadi, A., \& Dona, F. (2015). Faktor-Faktor yang Mempengaruhi Prestasi

Belajar (Studi Korelasi Pada Mahasiswa Pendidikan Matematika IKIP PGRI Pontianak). Jurnal Pendidikan Informatika Dan Sains, 4(2), 233-246.

Sugiyono. (2016). Metode Penelitian Kuantitatif, Kualitatif Dan, R\&D. Bandung: Alfabeta.

Suryadi, Didi. (2010). Didactical Design Research (DDR) Dalam Pengembangan Pembelajaran Matematika 1, Jurnal ilmu pendidikan, (online), (http://ejurnal.fkip.upi.ac.id, diakses 17 april 2019). 